\title{
Gandhian Philosophy of Education: A vision for Social Inclusion in Education
}

\author{
Dr. Anil Prakash Shrivastava*
}

Assistant Professor \& Senior Research Fellow, Dharampal Shodhpeeth, 251 A, Shirdipuram, Kolar Road, Bhopal, 462042 Madhya Pradesh, India

DOI: $10.36347 /$ sjahss.2020.v08i03.002

| Received: 04.03.2020 | Accepted: 19.03.2020 | Published: 21.03.2020

*Corresponding author: Dr. Anil Prakash Shrivastava

\section{Abstract}

Gandhiji was a legend of his time. His vision and ideas are still enlightening the world today in twenty first century. His vision towards Indian society, culture and civilization was phenomenal. During his debut into the Indian politics, Gandhi ji has visited throughout the country for a year, there he saw deeply the real conditions of life and living status of people in villages and cities and imagined the resurgence of villages and cities through improvement in education. He led the freedom movement as well as prevention of untouchability, abolition of caste discrimination, Harijan salvation, liberation from superstition and evil practices, revival of women, village swaraj, panchayat-raj, Swadeshi, Khadi and also worked to awaken and unite the Indian public on social economic issues. He has realized that the villages in India were self-sufficient and every person was engaged in work according to his skill and ability and was contributing to the progress of the society. It is from here that he expressed his education philosophy. In fact, he was an advocate of an education in which each hand should get work to do and having its own skill apart from literary knowledge and thus every youth should participate in the development of their family, village country and society. He should not only stand on his own feet but also contribute to make his village and city prosperous. Connecting every section of the society with education and providing opportunity to work for each hand was his dream, in fact, this is the biggest key for self-reliance, development and inclusion in today's global era. Gandhiji in his education philosophy emphasized the need for a balanced use of mind and body rather than just literal knowledge, which is the greatest need of modern times. The Basic Education or 'Nai Taleem' was a result of his all-time experiment and philosophical integrity. The present paper is an attempt to thrown lights on his vision and philosophy of Education and discussing his ideas for social inclusion in the Education.

Keywords: Gandhian Philosophy, Social Inclusion in Education, Nai Taleem, Basic Education.

Copyright @ 2020: This is an open-access article distributed under the terms of the Creative Commons Attribution license which permits unrestricted use, distribution, and reproduction in any medium for non-commercial use (NonCommercial, or CC-BY-NC) provided the original author and source are credited.

\section{INTRODUCTION}

'My life is my message' is the immortal message of Mahatma Gandhi for humanity. He was a practical idealist; his spirituality was composed in practice. He believed strongly in the ultimate success of his life-purpose, "To unite all the people of the world together, not as conflicting but as a whole" [1, 2]. He described himself as curious about truth and a petty explorer of the science of non-violence. Mahatma Gandhi's visit to England was the time when he was introduced to different people in a new place, new environment and new culture, some of whom he met for the first time and some of whom he had read about. He studied many books and this study helped to enhance his personality and gave him an opportunity to develop his perspective on various subjects and issues, these include 'Geethaji' (The Song Silsial) translated by Edwin Arnold, Arnold's 'Buddhacharit' (The Light of
Asia) and the Bible, the 'Giri Pravchan' (Giri discourse) of Jesus in the New Testament, which had a good influence on him. He then read John Ruskin's 'Un Two This Last', which he received in 1904 from Henry Pollock, while moving to Natal from Johannesburg in South Africa [3, 4]. This affected his philosophy the most. He was greatly influenced by the social and economic ideas given in it and later it became the basis of his socio-economic philosophy. Returning from South Africa, he traveled all over India on the suggestion of his political guru, Mr. Gopal Krishna Gokhale [5]. This tour gave him an opportunity to connect with the soul of India, its villages. In one year, tour of India, he saw the real picture of India, where thousands and millions of people were living their lives with hard work in the villages of India. Along with the social and economic diversity of India, social evils like, caste system, untouchability, pathetic condition of 
women were holding the society. Poor peasants and laborers were in the clutches of moneylenders and landlords [6]. Real conditions of life and living status of people in villages and cities. This socio-economic condition shocked and herd him inwards. As a result, he not only led the freedom movement as well as fought for the prevention of untouchability, abolition of caste discrimination, Harijan salvation, liberation from superstition and evil practices, revival of women, village swaraj, panchayat-raj, Swadeshi, Khadi and also worked to awaken and unite the Indian public on social economic issues [7-10].

\section{Vision of Constructive work}

Gandhiji's creative program is the attainment of complete swaraj by right and non-violent means. Communal harmony, prevention of untouchability, Liquor detainee, Khadi, Rural industry, village cleaning women empowerment, farmers and labors welfare and economic equality are some of the major works introduce for social inclusion in society. He saw that the villages in India were self-sufficient and every person was engaged in work according to his skill and ability and was contributing to the progress of the society. This was a real example of Social inclusion within the society and It is from here that he expressed his education philosophy.

\section{Wardha Scheme of Education or Basic Education}

Gandhi ji has expressed his views on Education through a series of various articles in 'Harijan', which later on developed in to Wardha Scheme or Basic Education. On 22 and 23 October, 1937, Mahatma Gandhi presented this new scheme of basic education at the All India National Education Conference in the presence of educationists, national leaders and social reformers on the occasion of the Silver Jubilee celebrations of Marwadi High School, Wardha. It was called Wardha Shiksha Yojana or Nai Talim. It was a seven-years basic education plan through the mother tongue. After approval of the proposals of this scheme, a committee was formed under the chairmanship of the Principal of Jamia Millia, Delhi, Dr. Zakir Hussain and he was tasked to prepare the plan for the Basic Education. The report submitted to the Haripura Congress session in February 1938 was accepted by the committee. This report is popularly known as Wardha Education Scheme and is the basis of Basic Education.

According to "him knowledge is not education in itself. Therefore, I will make Shri Ganesh of child education by teaching him some handicrafts and making him capable of production from the moment he starts his education. Thus, each school can be selfsufficient." According to Gandhi ji, the labor to be done wisely is the true primary or adult education. Education and labor are not different from each other. The aim of the Basic Education was to explain to children the pride of hard work from childhood. The plan has stated that "the current education system of the country cannot somehow meet the needs of the country." Whatever benefit is gained by this education, the main tax paying section of the country is deprived. Therefore, the course of primary education should be at least seven years, by which knowledge can be given up to matriculation. Instead of English, a good industry should be added. For the purpose of all-round development, all education should be given by any industry as far as possible so that the expenses of education can also be paid. It is important that the government purchases those things at a price fixed by the state. "In addition of 'Harijan' on $11^{\text {th }}$ Sept. 1937 Gandhi ji had expressed that hand work will be the focal point of all this planning. hands-on training will not mean that students make items worth keeping in the school museum or make toys that have no value. They should make such items which can be sold in the market. He envisioned that with the use of physical works and mental ability students of the entire society and different culture will be able to earn their livelihood as well as education to help the society. Gandhiji formulated the following basic principles of education:

- There should be free and compulsory education for children between 7 and 14 years of age.

- The medium of instruction should be the mother tongue.

- Literacy alone cannot be called education.

- Education means the development of human qualities of a child.

- Education should be in such a way that there is harmonious development of the body, heart, mind and soul of the child.

- Education of all subjects should be imparted through local production industries.

- Education should be such that it can free the youth from unemployment.

He also introduced some Model guidelines or rules for education in Aashrams such as:

- Boys and girls should be educated together. This childhood should be considered 8 years.

- They should be educated mainly on physical labor.

- Taking alphabets knowledge as part of beautiful writing art, the first child should be taught to draw the shapes of the earth.

- Children should learn to read before writing.

- Children should feel sports like education, sports are also a part of education, and they should enjoy it.

- The entire education of children should be imparted through mother tongue.

- Second period, he set it from nine to sixteen years.

- In this period, along with physical labor, the time of writing studies should be increased as per the need. 
- The child should try to be efficient to take part in the business of his parents.

- Girls should get trained in sewing embroidery and kitchen work.

- The third period was from 16 to 25 years.

He tried to implement all these in daily life activities of his Sevagram and Sabarmati aashram.

\section{Relevance in Modern Age}

In the current 21st century, the education philosophy of Mahatma Gandhi for social inclusion of students, people and community is completely relevant and useful. Holistic development of Body, mind and soul of a children and developing self-reliance in youth are the need of the hour. This would certainly provide ample opportunities to study further in today's era of revolution in information and communication and prepares them to use their physical and mental abilities more efficiently. In the time of commercialization and globalization, the challenges of unemployment and sustainable development can be addressed by adopting the Gandhiji's educational philosophy to make it economically self-reliant and balanced society.

\section{CONCLUSION}

In this way, Gandhiji presented a comprehensive philosophy of education for the social development and promote social inclusion through education. Which promotes physical exertion, selfreliance and self-dependency. Develops positive qualities in the child by discharging his duties and duties towards society and family. Gandhi's education philosophy shows the importance of professional as well as work experience in the course.

Implications: The following implications of Gandhi's education philosophy can be given:
1. By following Gandhiji's education philosophy, self-reliant, self-reliant youth can be prepared who not only conduct their livelihoods themselves but will also help in making society self-reliant.

2. Bringing girls and women education into the mainstream, eliminating the discrimination between women and men, giving impetus to the development of women's education, providing special facilities for vocational and technical education, and proper arrangements for the education of SC and ST children. Can prove to be consistently effective in the direction of Social Inclusion.

3. All these efforts embody the teachings of Gandhi's self-reliance and demonstrate the relevance of his philosophy.

\section{REFERENCES}

1. Gandhi MK. Hind Swaraj, Serva Seva Sangh Prakashan, Rajghat Varanasi.

2. Gandhi MK. The story of my Experiment with truth, Navjivan publication Ahmedabad.

3. Gandhi MK. Mangal Prabhat, Navjivan publication Ahmedabad.

4. Gandhi MK. Sarvoday, Navjivan publication Ahmedabad.

5. Gandhi MK. Basic Education, Navjivan publication Ahmedabad

6. Gandhi MK. Creative works, Navjivan publication Ahmedabad

7. Guha R. Gandhi the years that changed the world (1914-1948), 2018.

8. Kripalani JB. Gandhi his life \& thought, Publication Division, 2005.

9. Shukla. Dr Dhruv, Sakshatkar (Oct.Nov.Dec.2019), Sahitya academy, Govt of Madhya Pradesh.

10. Upadhyay, Haribhau, Bapu katha (1920-1948) Sarva Seva Sangh Publication Varanasi. 